\title{
Decadência e renascimento do Córrego Cheong-Gye em Seul, Coreia do Sul: as circunstâncias socioeconômicas de seu abandono e a motivação política por detrás do projeto de restauração
}

\author{
Decay and Rebirth of the Cheong-Gye Stream in Seoul, South Korea: \\ the socioeconomic circumstances of its abandonment and the political \\ motivation behind the restoration project
}

Lucimara Flávio Reis ${ }^{[a]}$, Rodrigo Luiz Medeiros da Silva ${ }^{[b]}$

\author{
[a] Universidade de São Paulo (USP), São Paulo, SP, Brasil \\ [b] Universidade Federal da Integração Latino-Americana (Unila), Foz do Iguaçu, PR, Brasil
}

\section{Resumo}

Descreveremos e contextualizaremos o processo de decadência e renovação do entorno do Córrego Cheong-Gye, em Seul, Coreia do Sul. Explicaremos que, no passado, o córrego foi degradado por severa poluição e, mais tarde, tamponado por uma estrutura de concreto. Mais adiante, ergueu-se sobre essa cobertura uma via elevada. A paisagem resultante, uma estrada suspensa ladeada por vielas apinhadas de lojas populares, era a face do centro da capital sul-coreana até a virada do milênio. Por fatores de ordem política e econômica que discutiremos, decidiu-se descobrir o córrego e restaurar completamente o seu sistema hídrico. Com o projeto, buscou-se restabelecer o fluxo de pedestres para a região central, resgatando o contato dos habitantes com o veio d'água, mas também abrir novas possibilidades econômicas para a área, com a reconstrução e reocupação de todo o seu entorno. As principais intervenções urbanísticas contidas nesse projeto serão aqui nomeadas, bem como as motivações políticas subjacentes.

Palavras-chave: Córrego Cheong-Gye. Centro histórico. Obsolescência. Renovação urbana. Infraestrutura.

\section{Abstract}

This article will describe and contextualize the decay and renovation process of the Cheong-Gye Stream vicinities, in Seoul, South Korea. We will explain that, in the past, this stream was degraded by severe pollution, and subsequently overlaid by a concrete structure. Afterwards, an elevated road was built above that coverture. The resulting landscape, a suspended expressway, surrounded by alleyways overfull of popular shops, was the face of downtown Seoul until the new Millennium. For political and economic factors that we shall discuss, it has been decided to uncover the stream and completely restore its hydric system. The project sought to reestablish the flux of pedestrians to the central region, as well as to open new economic possibilities to the area, with the reconstruction and reoccupation of its surroundings. The main urbanistic interventions contained in this project will be named here, just as its results, just as the underlying political motivations.

Keywords: Cheong-Gye stream. Historic center. Obsolescence. Urban renewal. Infrastructure.

LFR é socióloga, mestre em Geografia Humana pela FFLCH-USP, aluna do Programa de Doutorado em Planejamento Urbano e Regional da FAU-USP, bolsista da FAPESP, e-mail: lucimara.reis@usp.br

RLMS é economista, mestre em Economia pela Unicamp, doutor em Sociologia pela FFLCH-USP, fellow da Korea International Foundation em 2011, professor adjunto de Economia Internacional da Unila, e-mail: rodrigo.silva@unila.edu.br 


\section{Introdução}

O crescimento da cidade de Seul pode ser descrito através da história da ocupação das margens do córrego Cheong-Gye ${ }^{1}$. Cortando a capital sul-coreana de oeste a leste e entre os montes Inwangsan e Bugaksan, o córrego corre pelo coração da cidade perfazendo $11 \mathrm{~km}$ de extensão. Sua história está intrinsecamente ligada à da cidade, tendo sido utilizado pela população desde o estabelecimento da Dinastia de Choson, em 1394, até a transformação de Seul em centro de uma imensa zona metropolitana, atualmente.

No bojo do intenso processo de urbanização, o córrego foi contaminado até ser, enfim, tamponado por uma cobertura de concreto respondendo a um imperativo imediato - diga-se, tecnicamente equivocado - de evitar as enchentes periódicas e esconder a poluição. Mas, ao que parecia ser seu sepultamento definitivo, seguiu-se um icônico renascimento, mediante um audacioso projeto urbanístico. Agora despoluído, o córrego desponta como um ativo paisagístico no centro financeiro da capital sul-coreana e atrai a curiosidade daqueles em busca de soluções para cidades cuja relação com os rios ainda precise ser rediscutida. A experiência acendeu debates sobre os mecanismos de intervenção no padrão de ocupação do entorno de cursos fluviais e lançou alertas sobre os efeitos secundários de iniciativas correlatas, seja discutindo os corolários para a circulação de veículos, para o clima local ou ainda como alerta para a valorização do solo na área circundante.

A conexão entre o projeto de renovação do Cheong-Gye e a variação nos preços dos lotes foi discutida extensamente por Jang \& Kang (in press), Bae (2011), Kang et al. (2012), entre outros. 0 problema do acesso à moradia foi discutido à luz da política de renovação da zona central e do processo de mudança nos usos do entorno do córrego, em trabalhos como os de Shin (2009), Shin \& Kim (in press), Ha (1984, 2005, 2004). Ali também discutem-se as implicações distributivas, que relativizam o êxito das iniciativas de renovação e tecem considerações sobre os riscos da gentrificação.

0 efeito do projeto no trânsito local foi apreciado por Chung et al. (2012). Já suas consequências para o clima do centro da cidade e sobre as "ilhas de calor"

\footnotetext{
1 "Cheong-Gye" é um nome próprio, enquanto que "Cheon" significa fluxo e pode ser usado para designar córrego. Assim, Cheong-Gye-Cheon significa Córrego Cheong-Gye. Evidentemente, Córrego Cheong-Gye Cheon é uma redundância que deve ser evitada.
}

foram alvo das análises de Han et al. (2007) e Kim \& Baik (2007). 0 significado ecológico do projeto foi avaliado por Kang et al. (2012) e Shin et al. (2011). Em conjunto, essa bibliografia ressalta as virtudes climáticas e ecológicas do projeto.

Apesar desse considerável acúmulo de referências, há um aspecto do projeto que ainda carece de reflexão acadêmica, especificamente, suas condições de implementação. Assim, que circunstâncias políticas e institucionais permitiram que uma intervenção tão radical fosse levada a cabo? Para compreender esse atributo, fundamental para qualquer proposição de replicar a iniciativa, buscaremos situar historicamente o processo de decadência e renovação que culmina com a reintegração do córrego Cheong-Gye ao tecido urbano. Para tanto, defenderemos duas teses:

1) A rápida degradação do córrego, culminando com seu sepultamento sobre uma avenida e um elevado, foi corolário da rápida transição econômica rumo à urbanidade industrial, conduzida sob um regime político autocrático e comprometido com certa acepção de progresso.

2) O ressurgimento do córrego resulta do amadurecimento da democracia sul-coreana, sob um quadro econômico afluente. Ou seja, em que pese o arcabouço não participativo do projeto em si, moldando-o como uma experiência de ares tecnocráticos, o projeto e sua execução são indissociáveis do aguçamento da disputa pela presidência da Coreia do Sul.

Para discutir nossas hipóteses, lançaremos mão de uma metodologia descritiva e simultaneamente analítica, enfatizando a história socioeconômica e a história urbana em busca de relações biunívocas, naquilo que concerne à região estudada. Paralelamente, faremos alusão a imagens pesquisadas ou colhidas in loco pelos autores, e revelaremos insights que nos foram transmitidos por um dos artífices do projeto, o Dr. Yang Yoon-Jae, vice-prefeito de Seul entre 20022006, que gentilmente nos concedeu uma entrevista no outono de 2011.

\section{A história do córrego durante a urbanização de Seul}

A morte e o súbito renascimento do córrego Cheong-Gye foram testemunhos das intensas transformações socioeconômicas que abarcaram a 


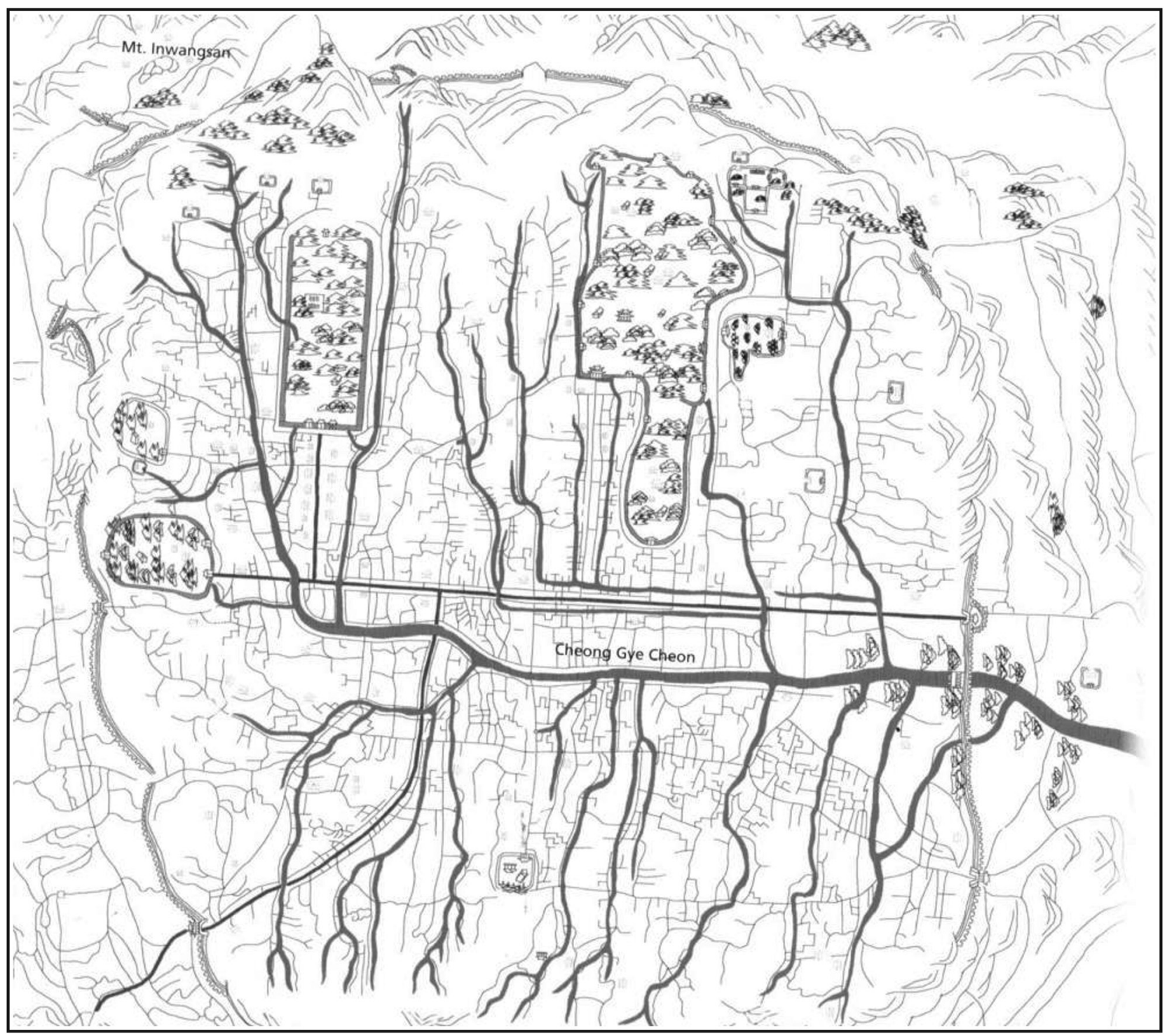

Figura 1 - 0 Cheong-Gye-Cheon e afluentes ocupando a velha Seul murada Fonte: Seoul Metropolitan Government (2005, p. 10).

sociedade sul-coreana desde o início dos 1900. A cidade de Seul principia o século como centro administrativo de um estado monárquico rigidamente burocratizado (Cumings, 1997, p. 72-73), que repousava sobre uma base econômica agrária movida pelo trabalho servil e cuja administração recaía sobre uma camada de funcionários letrados, os yang-ban ${ }^{2}$. A moeda nacional havia sido recentemente instituída, em 1894, e o comércio era embrionário, concentrando-se nos portões da muralha que envolvia a cidade (Figura 1). A atividade industrial mal começara, introduzida pelo capital estrangeiro em busca de vantagens locacionais.

\footnotetext{
${ }^{2}$ Yang-ban era a versão coreana dos mandarins chineses.
}

Ao centro da cidade destacavam-se os portões do Palácio Gyeongbok e, nas cercanias, corria em calha ancha o córrego Cheong-Gye (Figura 2).

Havia mais de 600 anos que o Córrego Cheong-Gye era usado como natural sistema de drenagem e esgoto da cidade e, conforme a população aumentava, crescia, na mesma medida, o número de inconvenientes ocasionados pelos transbordamentos das suas águas. Há provas escritas de enchentes destruidoras desde 1407, quando se forma uma "autoridade gerenciadora da água”, que mobiliza 52.800 pessoas para dragar e limpar os córregos urbanos. Já em 1760, o rei Yeongjio determina uma gigantesca intervenção de quase sessenta dias, engajando cerca de 200 mil trabalhadores em 


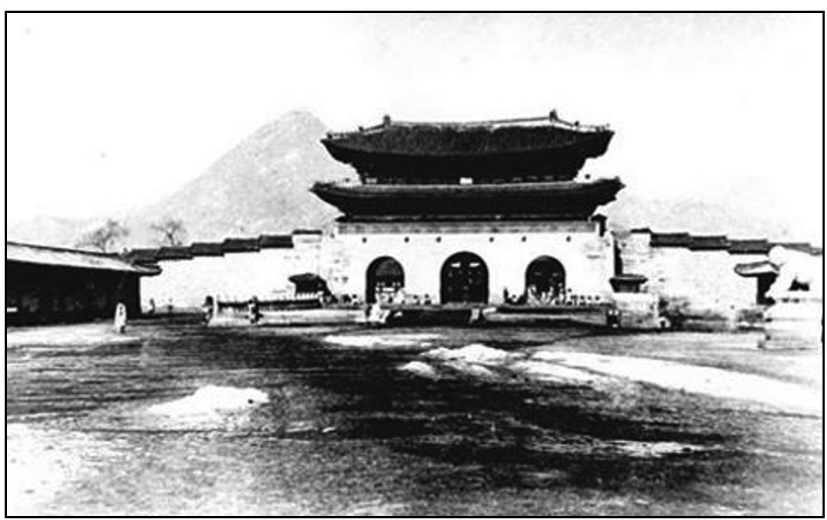

Figura 2 - Portões do Palácio e Córrego nos 1900 Fonte: Cidade Especial de Seul (2003, p.53).

serviços de dragagem, retificação e reforço da parede de pedra das margens do córrego. Desde então, novas obras viriam a ocorrer a cada 2 ou 3 anos, até o final da primeira década do séc. XX (Seoul Metropolitan Government, 2005, p.13). Mesmo assim, as monções continuaram a significar eventuais inundações para o centro de Seul.

No último quartel do século XIX, com a assinatura do Tratado de Kanghwa, os portos coreanos são abertos ao comércio com o Japão e a outros parceiros comerciais. Logo em seguida, cresce a presença militar japonesa na península e progressivamente se conforma um Protetorado. Buscando contrabalançar a influência japonesa, o governo coreano firma joint-ventures com o capital americano: a Hanseong Electric Company e a Seoul Fresh Spring Water Company. Mesmo assim, a Coreia é ocupada e formalmente anexada pelo Império Japonês, permanecendo assim entre 1910 e fim da II Guerra Mundial.

Nesse ínterim, Seul recebe substanciais investimentos industriais e amplas intervenções urbanísticas para legitimar a presença colonial estrangeira, como a Lei de Melhoramento Viário, de 1912 (Kim, 2012, p. 153), na qual vielas são destruídas em benefício de ruas mais largas, ou a Lei de Planejamento Viário de Chōsen ${ }^{3}$, aprovada em 1934 (Kim \& Han, 2012, p. 143-144), pela qual são instituídos zoneamentos preconizando alturas máximas e mínimas para as edificações (Kim \& Jang, 2002). Era o marco fundacional do moderno planejamento urbano em Seul. Ao fim dos anos 1930, a cidade já possuía bondes e uma coleção de

\footnotetext{
${ }^{3}$ Chōsen era forma japonesa de designar a Coreia, que para os coreanos chamava-se Choson. Esse plano é referido como "Chosun Civil Area Planning Enactment.
}

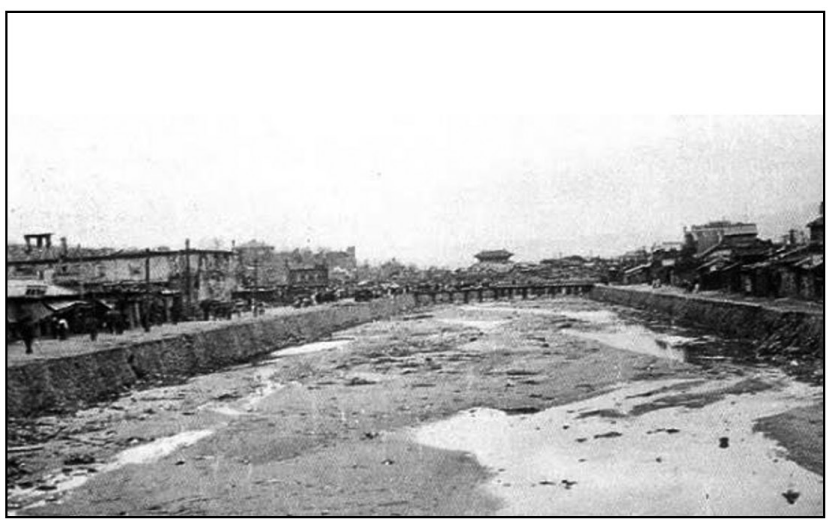

edifícios governamentais novos marcava a esplanada monumental (Figura 3), que até hoje se abre a partir do portão principal do palácio Gyeong-bok, localização simbólica onde foi agressivamente erigido um paço em estilo neoclássico para sediar o governo colonial.

Em trabalho clássico, Dennis McNamara (1990, p. 50-51) afirma que foi instituído, na Coreia, um capitalismo ao molde japonês, com o Estado e suas agências desempenhando um papel absolutamente central. Desenhavam-se políticas econômicas objetivando a operação dos zaibatsu, os famosos conglomerados financeiros e industriais japoneses. A partir do terceiro quartel do século XIX, são abertas as primeiras instituições financeiras modernas na Coreia, as filiais japonesas do First Bank e do Imperial Life Insurance e, após configurado o Protetorado, os japoneses criam o Bank of Korea, em 1909, precedido pelo Bank of Chōsen, em 1911. Em 1918 seria criado o Banco Industrial de Chōsen - embrião do futuro Korea Development Bank —, para atuar no segmento de crédito de longo prazo.

Por sua vez, o parque industrial erigido sob tais circunstâncias justificava-se pela indisponibilidade de matérias-primas nas ilhas do Arquipélago Japonês. Assim, a maior parte da produção manufatureira da colônia era encaminhada para a metrópole - em 1930, 1/3 da produção era exportada, e este contingente saltaria para $2 / 3$ em 1940 (Jones \& Il, 1980, p. 24).

Em face dos problemas sanitários ocasionados pela urbanização e pelo primado da abertura de vias para passagem de veículos, já no ano de 1895 planejou-se a cobertura do Cheong-Gye-Cheon e a construção de vias pavimentadas sobre o córrego. Os planos não sairiam do papel antes da ocupação 

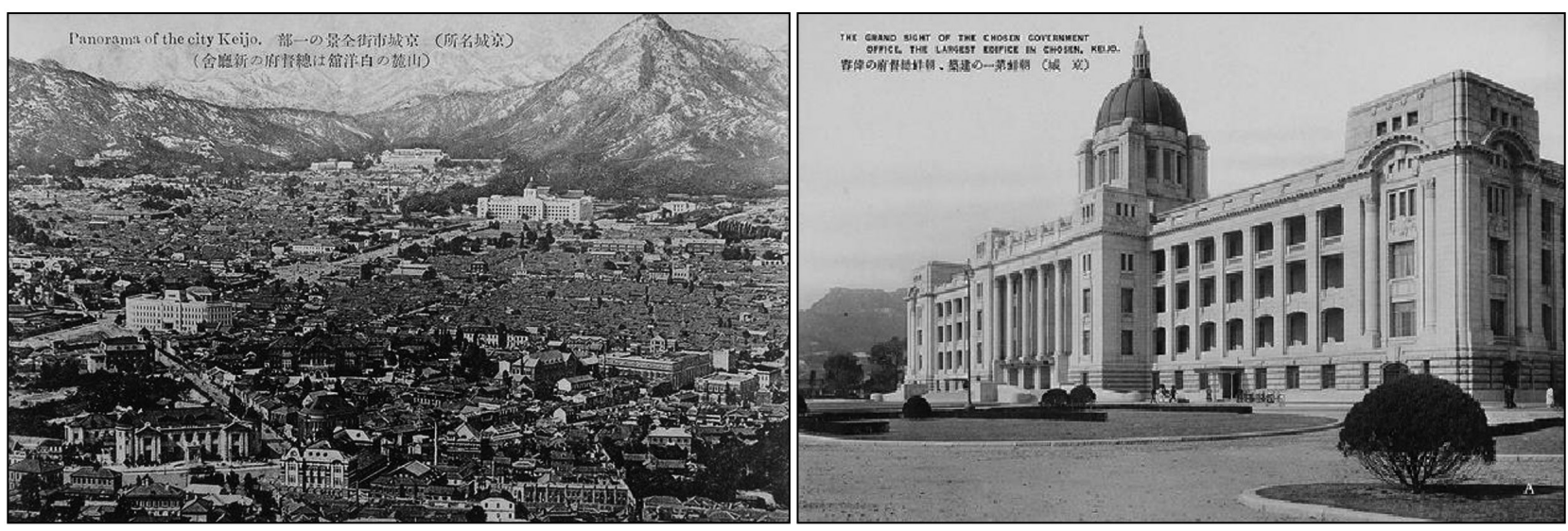

Figura 3 - 0 "Capitólio" neoclássico que substitui o portão do Palácio Gyeongbok (ao pé do Monte Bugak) e a esplanada aberta adiante dele Fonte: Antigos Cartões Postais.

japonesa, mas o córrego e áreas adjacentes passariam por várias intervenções urbanísticas até as primeiras décadas do século XX. Nesse período, marcado pela efervescência econômica subsequente à abertura dos portos, a cidade se desenvolve como núcleo receptor de estrangeiros, notadamente japoneses, para quem novas áreas residenciais ao longo do córrego foram destinadas. Concomitante a esse processo e selando uma duradoura reestruturação no tecido urbano de Seul, ruas foram construídas e pavimentadas em substituição às centenárias e estreitas vielas de pedestre, conformando, aos poucos, um padrão de modernidade na capital coreana. Com o crescimento da cidade durante a ocupação japonesa, iniciam-se as obras de cobertura do córrego. 0 desmantelamento do Império Colonial, em 1945, foi seguido pela ocupação militar americana e, enfim, pela devastadora Guerra da Coreia, entre 1950 e 1953. Esses eventos representaram dois duros golpes ao país. 0 primeiro, claro, foram os danos físicos que o conflito acarretou. 0 segundo foi o abrupto corte dos laços econômico-produtivos que uniam os organismos industriais coreano e japonês.

A guerra fratricida entre Sul e Norte, intervencionada pelos EUA, deixa um saldo de destruição particularmente grande para Seul, que perde $2 / 3$ de seus habitantes entre 1950 e 1952 e a maior parte da infraestrutura urbana instalada. Com o fim do conflito, a fome se dissemina pelo país e o êxodo de regresso traz massas de "retornados" à capital (Ha, 2004). No cômputo final, a população de Seul salta de um milhão, em 1950, para mais de 1,5 milhão, em 1955. Ao mesmo tempo, a secessão do país priva a manufatura da capital do suprimento hidrelétrico abundante apenas no Norte.
As obras de tamponamento e manutenção do córrego seriam interrompidas diversas vezes durante as descontinuidades históricas que se abateram sobre a península, até o seu abandono. Como agravante, o pós-guerra é marcado pela migração de refugiados do Norte recém-secionado. Nesse contexto de cataclismo econômico e pauperização e devido à falta de habitação adequada na capital, a população se instalava no entorno do córrego, em casas precárias construídas sobre palafitas (Figura 4).

Mais uma vez, a história da cidade seria tipificada pela ocupação do Cheong-Gye. Barracos se espalham pelas margens, criando favelas comparáveis às latino-americanas. Pobreza e miséria tomariam o lugar das incertezas geradas pelas sucessivas guerras. Tal qual tantos barracos utilizados como abrigo no mundo "em transição", ali também as casas eram construídas, uma ao lado da outra, em estacas de madeira fincadas à margem do leito do córrego. Enchentes e incêndios eram periódicos (Figura 5) e, juntamente com a falta de insolação adequada e com as possibilidades de contaminação da água, contribuíam para deixar a população residente em permanente estado de atenção.

Nesse ínterim, a Coreia do Sul se torna refém da ajuda oficial norte-americana, pois, para assegurar o funcionamento do país, demandavam-se doações humanitárias e militares. Paradoxalmente, a dependência não parecia afligir o então presidente Syngman Rhee, que parecia acreditar na perenidade dos donativos como algo garantido no contexto da Guerra Fria (Krueger, 1982, p. 58, 75). Essa postura começa a mudar a partir de 1957, quando autoridades norteamericanas manifestam a intenção de diminuir o 

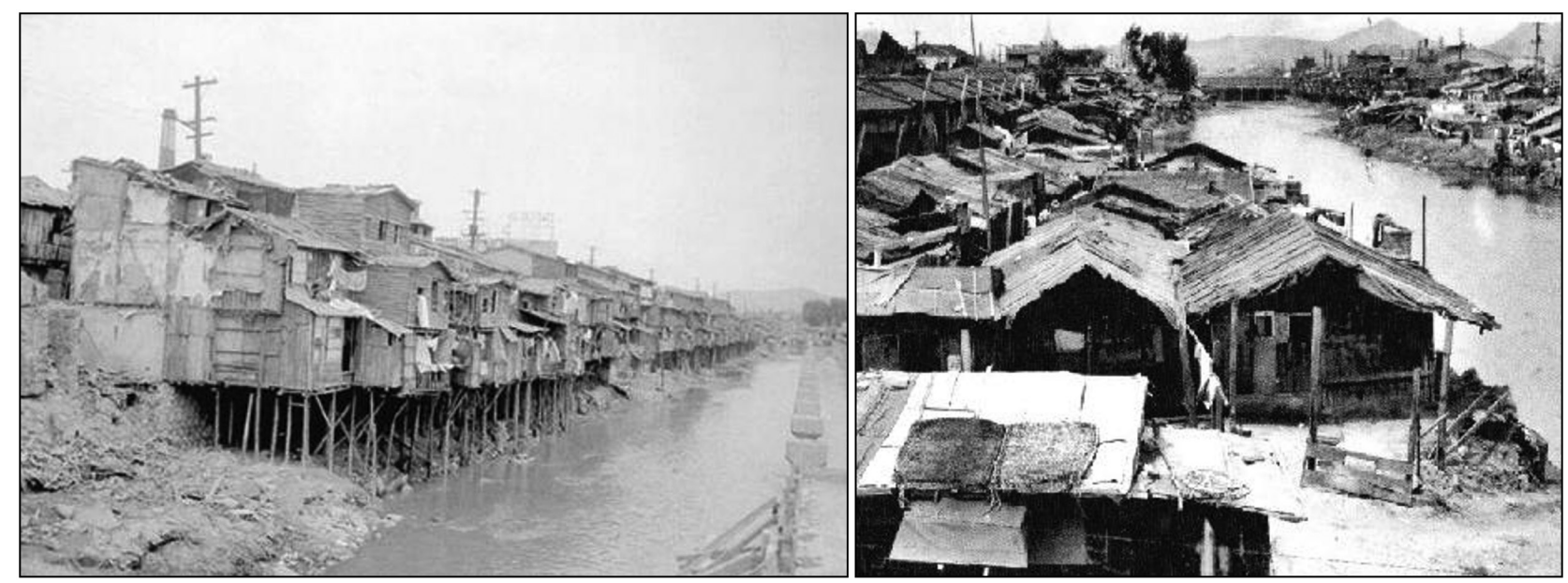

Figura 4 - 0 córrego tomado por barracos nos anos 1950

Fonte: Cidade Especial de Seul (2003, p. 54) e Seoul Metropolitan Government (2005, p. 32).
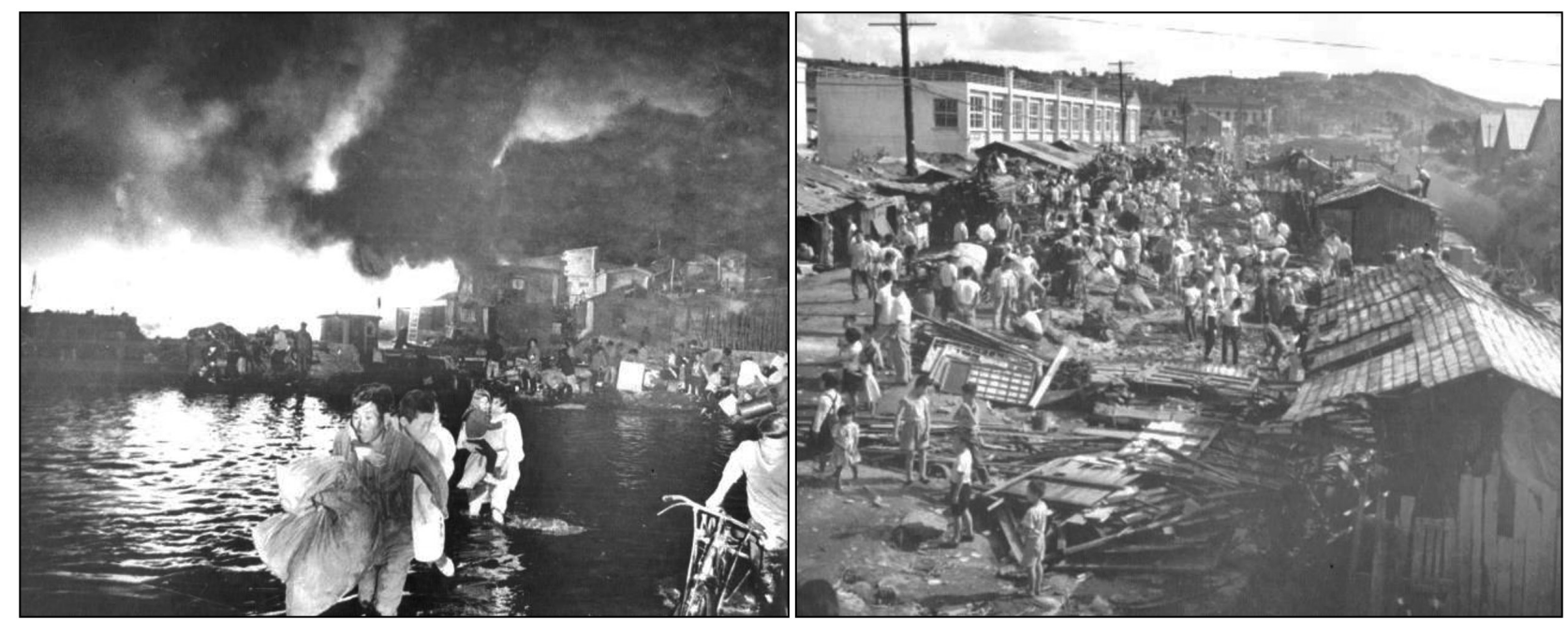

Figura 5 - Fogo e remoção dos barracos à margem do Cheong-Gye Fonte: Seoul Metropolitan Government $(2005$, p. 34, 36).

volume de ajuda e que o arcabouço político-econômico sul-coreano deveria passar por profundos ajustes e adquirir contornos mais autossustentados. A mudança de regime econômico, no entanto, tardaria mais alguns anos. Os anos Rhee (1948-1960) foram marcados por baixo dinamismo econômico, acarretando em escassos fundos para intervenções urbanas na capital. O tamponamento do córrego não teria como ser levado adiante.

A Revolução de abril de 1960, nacionalista e favorável à democracia, sela o fim do governo Rhee. Como reação conservadora e com o beneplácito norte-americano, inicia-se o período ditatorial-militar, que vigorará por 33 anos, até a posse de Kim Young Sam em 1993. Neste contexto, o período entre
1960 e 1965 representaria um divisor de águas na política de crescimento industrial sul-coreana, com o prevalecimento das exportações sobre a estratégia de industrialização atada ao mercado interno (Krueger, 1982, p. 80-82). Há indícios incontestes de que esse câmbio foi firmemente encorajado e contou com grandes benefícios competitivos ofertados pelos Estados Unidos, como abertura de mercados e prioridade em licitações (Woo, 1991). Sob impulso externo e com méritos próprios bastante repercutidos entre os analistas do desenvolvimento (Amsden, 1992), a partir do Primeiro Plano Quinquenal de Desenvolvimento Econômico, em 1962, a República da Coreia começa a exibir uma sequência notável de taxas de crescimento do Produto Interno Bruto. Configurava-se aquilo que 
seria conhecido como "Milagre do Rio Han", em alusão ao rio no qual o Córrego Cheong-Gye deságua.

Com o crescimento econômico acelerado, apoiado no crescimento industrial urbano, a cidade de Seul experimenta mudanças profundas, que conformariam a hodierna Coreia do Sul. 0 "inchaço" ocasionado pelo influxo populacional no pós-guerra, acompanhado da intensificação do uso do automóvel privado como meio de transporte, implicava a necessidade de uma continuada reorganização espacial. É no contexto da transição de regime econômico, de aceleração do crescimento e recomposição das condições fiscais necessárias a grandes intervenções urbanísticas, que são retomados os trabalhos de cobertura do Cheong-Gye-Cheon (Figura 6).

0 antigo centro, margeado pelo córrego Cheong-Gye e ocupado por pequenas casas de madeira unifamiliares, não se adaptava às novas necessidades comerciais, administrativas e financeiras da cidade. Inicia-se um intensivo processo de verticalização, acompanhado de tentativas, por parte dos incorporadores imobiliários, de impulsionar a ocupação de novas áreas, como a região a sudoeste do Rio Han, Kangnam, que restara desocupada até meados dos anos 1970. Com isso, começa a formação de subcentralidades (Lee \& Shin, 2012) e, em 1971, o governo nacional estabelece cinturões verdes ao redor de Seul, redundando em nova pressão de adensamento no centro da cidade (Rii \& Ahn, 2002).

\section{O elevado construído sobre o tamponamento do córrego e o declínio do centro histórico}

Desde a fundação da cidade como capital da Dinastia de Choson, o entorno do córrego fora habitado por pessoas de várias classes sociais, variando desde o yangban até a gente mais simples. A rigor, as áreas mais altas eram ocupadas pelas classes sociais proeminentes, enquanto que os mais pobres ocupavam as partes mais baixas e mais sujeitas a alagamento (Figura 7).

Com a intensificação da urbanização, a poluição hídrica e a crescente frequência dos alagamentos coincidem com a difusão da visão ocidental de uma modernidade revestida de concreto armado, marcada pela onipresença do automóvel particular sobre viadutos desimpedidos (Figura 8). É sob esse contexto cultural, cuja projeção urbana individualista era alvo da crítica da "contracultura" no próprio Ocidente (Amin, 1992), que emerge o projeto de construção de uma via expressa sobre a laje que ora recobria o córrego, conectando o centro aos bairros adjacentes (Figura 9).

As obras são iniciadas em 1967 e, em 1971, a Cheong-Gye Expressway seria entregue à população, modificando drasticamente a paisagem urbana com seus $5.650 \mathrm{~m}$ de comprimento por $16 \mathrm{~m}$ de largura. A construção da via elevada cria uma barreira entre bairros cortando acesso a bens urbanos fundamentais e, ao fazê-lo, provoca uma mancha de obsolescência e degradação ao seu redor. A colossal estrutura imprimiria sua profunda marca no entorno, com
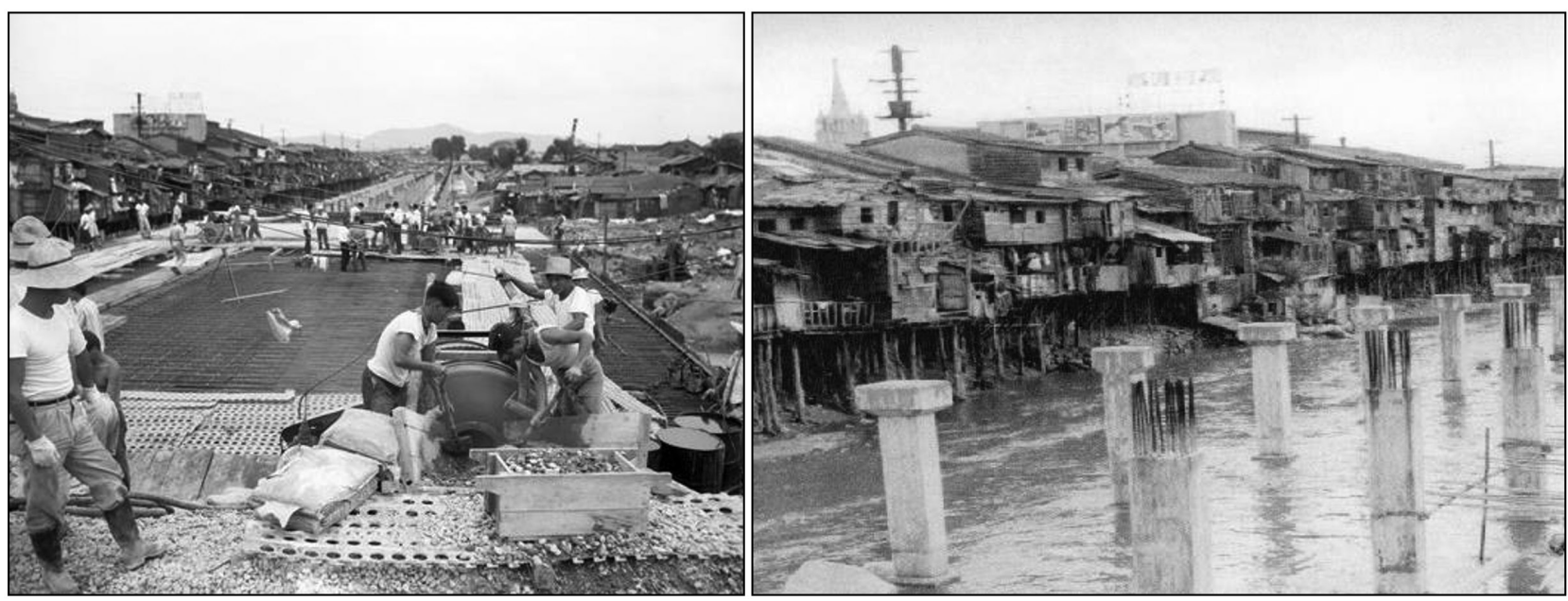

Figura 6 - A construção das lajes sobre o Cheong-Gye Fonte: Seoul Metropolitan Government (2005, p. 38). 


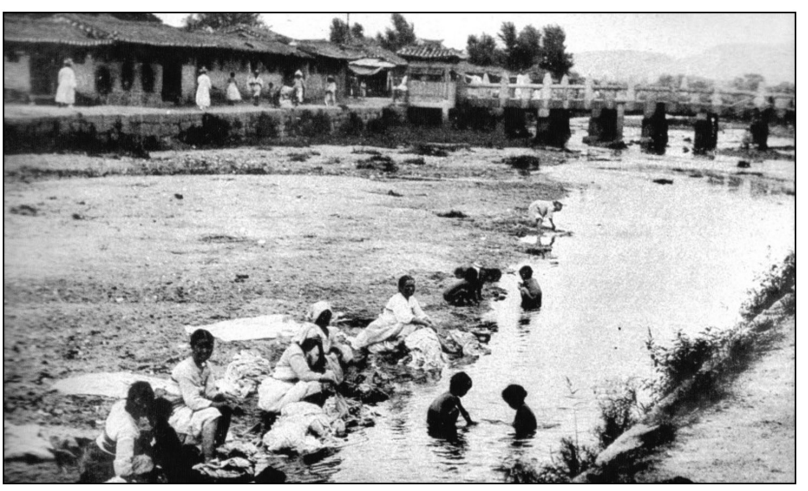

Figura 7 - 0 trabalho e o lazer no Córrego Cheong-Gye Fonte: Seoul Metropolitan Government (2005, p. 20).

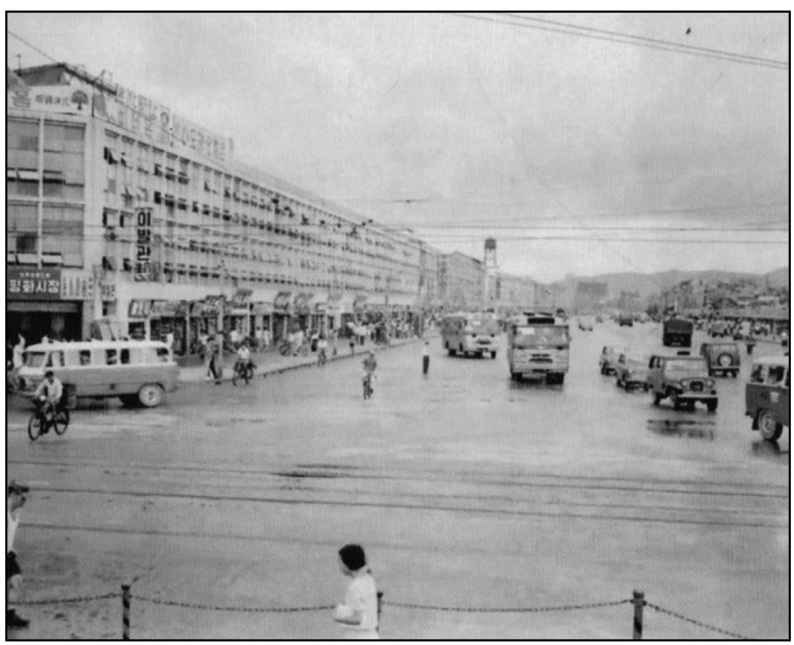

Figura 8 - A área do córrego expropriada pelo automóvel Fonte: Cidade Especial de Seul (2003, p. 70-71). um impacto gigantesco sobre a identidade da velha cidade que se modernizava. Além disso, como discute Chung et al. (2012), o projeto nunca cumpriu, como contrapartida, seu objetivo inicial de tornar mais fluido o trânsito no centro da cidade.

Se, no longo prazo, o elevado definitivamente não privaria Seul dos impasses de circulação imanentes à opção pelo automóvel como meio preferencial de transporte, naquele momento, o governo sul-coreano perseguia o desenvolvimento de uma indústria automotiva nacional (Chu, 1994). Era preciso popularizar os automóveis, pois, sem um mercado
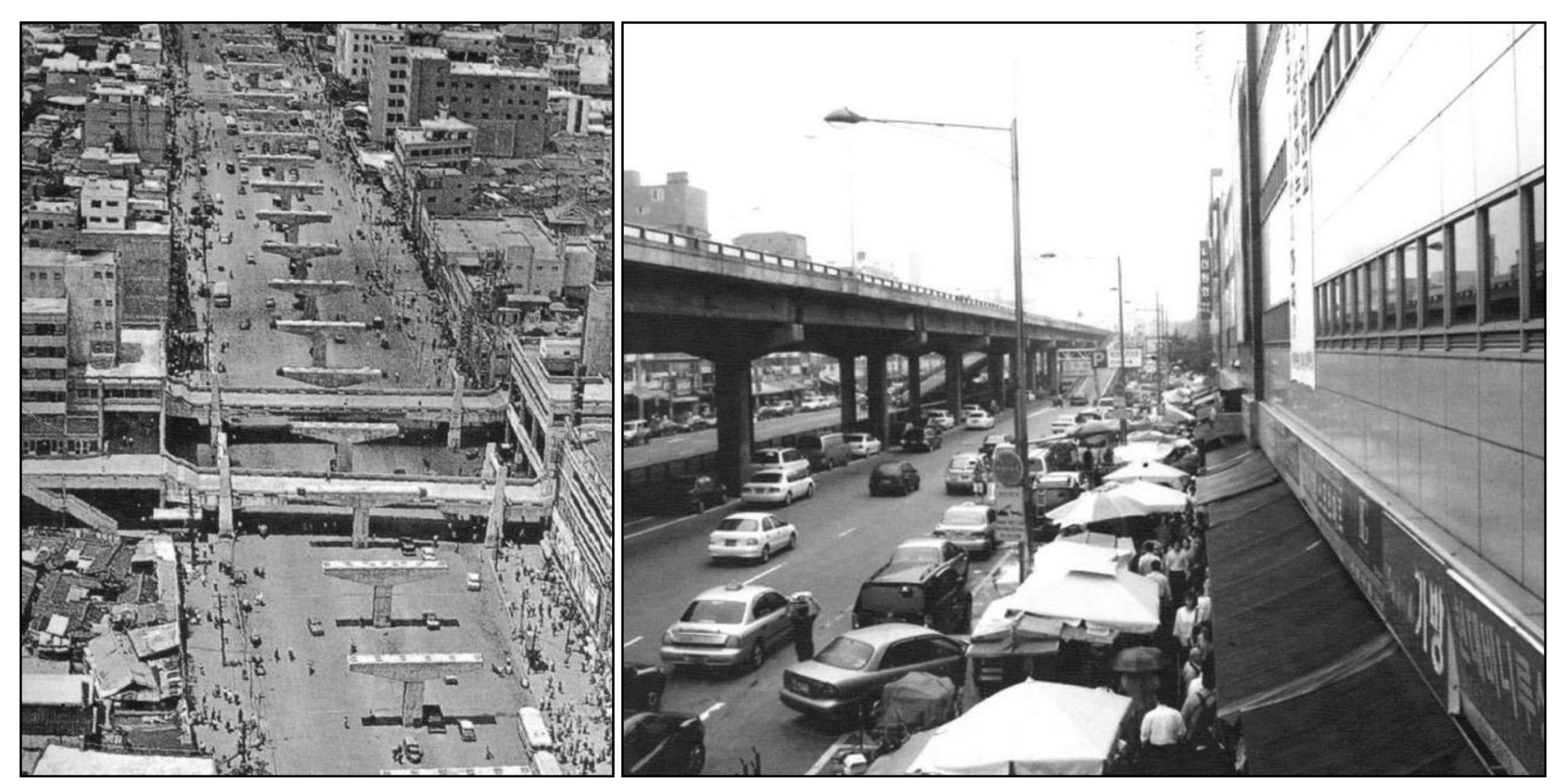

Figura 9 - A via elevada sobre 0 antigo leito do Cheong-Gye

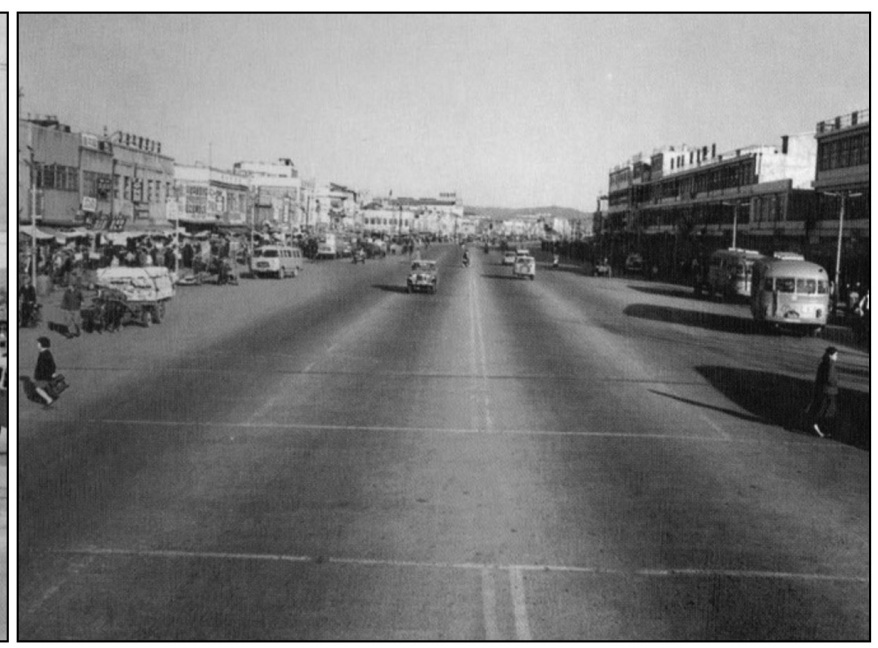

Fonte: Cidade Especial de Seul (2003, p. 75) e Seoul Metropolitan Government (2006, p. 11). 
interno substancial, a produção doméstica não teria como deslanchar. 0 elevado sinalizava uma opção política por privilegiar as opções de deslocamento dos detentores de automóveis particulares, instigando seu consumo e produção.

Com o término das obras, o entorno do córrego torna-se a maior área comercial da Coreia do Sul, abrigando mais de 100 mil pequenas lojas varejistas, atacadistas, depósitos e mercados tradicionais. Embora ali se encontrassem artigos diversificados, desde velhos mercados de vegetais, comidas de rua e objetos de segunda mão, boa parte dos produtos comercializados era então constituída de contrabando ou falsificações, conformando um pujante comércio popular. Se, em um primeiro momento, o concreto armado do novo equipamento público fora associado à modernidade, nas décadas posteriores ele seria lembrado como o grande responsável pelo processo de degradação do centro.

Em que pese o impacto paisagístico negativo do elevado, a rápida transição de usos do solo deve ser entendida como um fenômeno mais complexo, indissociável do processo de declínio dos centros históricos das grandes cidades do mundo capitalista, observado a partir de meados do século XX e intensificado justamente na década de 1970 (Friedrichs, 1992; Sen \& Bell, 2001; Januzzi \& Razente 2007). Assim, também a deterioração do entorno do Cheong-Gye-Cheon se insere em um processo maior de declínio do centro histórico da cidade de Seul. E tal qual acontecera em outros lugares, ali também fora acompanhada - ambos os processos se apoiam reciprocamente pela conformação de novo eixo de desenvolvimento de centralidade. Com o aglutinamento de uma área metropolitana ultrapassando os 10 milhões, já no início dos anos 1970, o centro, antes delimitado ao entorno de uma parte do córrego Cheong-Gye, estende-se e se multiplica para além do Rio Han. Formam-se novos subcentros, que, progressivamente, ofuscam o centro velho. Todos os negócios que antes eram prerrogativa da zona central, começam a espraiar-se por áreas em que o preço do $\mathrm{m}^{2}$ seja mais competitivo ou para onde a população consumidora se volte em busca de novos lazeres, como Gangnam, a sudoeste do Rio Han (Jun \& Ha, 2002; Lee \& Shin, 2012).

0 crescimento demográfico ostentado pela cidade de Seul, nesse período, foi o produto de um acelerado processo de industrialização. Em 1972, ao lançar o Terceiro Plano Quinquenal, o governo do Gal. Park proporia uma política industrial que levaria a uma transição da produção em direção aos ramos mais sofisticados da indústria. Esse planejamento estatal, no entanto, teria uma recepção negativa pelos organismos de fomento internacionais ${ }^{4}$, dependentes dos financiamentos externos. Mesmo assim, após o Choque do Petróleo, teria início um respeitável ciclo de crédito internacional fundado no acúmulo de petrodólares em mãos privadas. Era o ciclo do chamado Euromarket, que inunda o Terceiro Mundo de crédito barato e pouco exigente em garantias. No entanto, segundo Canuto (1994, p. 10), a combinação de competência do Estado e da grande empresa privada em aproveitar as oportunidades singularizaria a experiência sul-coreana como caso de sucesso de industrialização tardia e periférica.

Para a maioria dos países que se endividaram no Euromarket, a pujança da década de 1970 foi não mais que o prelúdio de uma década de "crises da dívida". Com a elevação nos juros norte-americanos, até meados da década de 1980, trinta e oito países precisariam repactuar seus vencimentos em negociações multilaterais. A Coreia do Sul é poupada desse destino por conta do generoso pacote de socorro japonês, cujas liberações incidiram fortemente sobre o período (Lee, 1985), poupando os projetos de desenvolvimento socioeconômico contidos no Quinto Plano Quinquenal. A este plano, seguiram-se ainda mais dois, respectivamente entre 1987-91 e 1992-97. Em conjunto, os projetos envolvidos conduzem a indústria sul-coreana à III Revolução Industrial, sincronicamente aos países tecnologicamente mais avançados. Naquilo que concerne ao tecido econômico, a Coreia do Sul havia enfim convergido ao padrão dos países mais afluentes. Os fundos públicos disponíveis para intervir no espaço urbano aumentaram de forma exponencial, suscitando propostas cada vez mais ousadas de redesenho da cidade.

A cidade de Seul, no final da década de 1990, havia se tornado a próspera capital do principal "Tigre Asiático". O sucesso econômico alcançado pelo país possibilitaria um salto de desenvolvimento humano sem precedentes no mundo, fazendo da capital alvo da atenção internacional. Os eventos esportivos da década de 1980 também serviriam como impulsionadores dessa nova visibilidade.

\footnotetext{
${ }^{4}$ O relatório 332-KO, emitido pelo Banco Mundial no ano de 1976, deixa claro considerar irreais os planos do governo sulcoreano (Medeiros da Silva, 2012).
} 


\section{Democracia após o "Milagre do Han"}

Elevada ao patamar de "Cidade Global" ainda nos anos 90, a capital do "Milagre do Rio Han" se via numa encruzilhada. Morfologicamente, Seul era uma cidade estruturada à luz do fordismo, com imensas avenidas, vias elevadas, túneis viários e poucas áreas verdes de lazer. A economia do país, contudo, havia se convertido em "caso de estudo" de superação do fordismo, extraindo o máximo proveito de setores econômicos emergentes (Lee, 2003). Colocava-se diante do Governo Metropolitano uma opção histórica crucial: insistir em um modelo de desenvolvimento urbano com base no paradigma produtivo do passado ou propor outra abordagem para resolução dos problemas urbanos.

Esse desafio surge em um contexto político inteiramente novo, marcado pela emergência de eleições relativamente livres e crescentemente competitivas e no qual a alternância de poder tornar-se-ia possível após 1997. Ao final dos anos 1980, aumenta-se a pressão do governo Reagan sobre a ditadura do General Chun. Seul, vitrine das virtudes do capitalismo, não devia continuar indefinidamente sob um governo ditatorial. Desde a ótica norte-americana dos estertores da Guerra Fria, era preciso festejar as Olimpíadas de Seul sob o mínimo de pluralismo político, garantindo-se que o "Milagre do Han" não fosse eclipsado por noticiários sobre práticas de tortura ou dando voz a presos políticos (Gills \& Rocamora, 1992).

Assim, em 1987, pouco antes das Olimpíadas, têm lugar as primeiras eleições diretas na Coreia após quase três décadas de ditadura. No pleito, a oposição civil se fragmenta ante dois nomes - Kim Young-Sam e Kim Dae-Jung, ícones do segmento de centro-esquerda do campo político emergente. Esta divisão acaba propiciando a derrota de ambos, com a consequente vitória de mais um general, Roh Tae Woo. A situação continuaria no governo até 1993. Pior, em 1990, em um movimento político imprevisto, o partido político do General Roh Tae-Woo se funde com o do oposicionista Kim Young-Sam. ${ }^{5}$ Esta aliança permitiria, em 1992, a vitória eleitoral de Kim, primeiro civil no poder desde Syngman Rhee (1948-1960). No entanto, sua vitória não sinaliza nenhuma substancial alternância de poder.

\footnotetext{
5 Para informações sobre o intricado jogo político que levou à excêntrica fusão de forças políticas na Coreia, veja Bedeskiee (1995).
}

Embora o ritual democrático exista desde 1987, um sistema político-eleitoral competitivo e representativo de camadas mais amplas da população é algo recente na história coreana. A eleição de Kim Dae-Jung, em 1997, no fulcro da Crise Financeira Asiática, representou a primeira alternância pacífica de poder da história. Assim, ainda que a industrialização sul-coreana tenha sido integralmente conduzida sob uma conjuntura política opressiva, o país principia o Milênio sob um presidente saído da esquerda católica. Essa inflexão rumo à esquerda se aprofunda ainda mais com a presidência de Roh Moo-Hyun (2003-2008), nacionalista, crítico da ditadura e defensor da unificação pacífica com o Norte Comunista.

No entanto, as forças conservadoras preferiram construir uma alternativa política menos radical em torno da figura conservadora de Lee Myun-Bak, prefeito da capital entre 2002 e 2006 (Figura 10). Para adquirir projeção nacional, Lee precisava realizar algum feito memorável. $\mathrm{E}$ é nesse contexto que ele se acerca de uma política urbana que rebate o "rodoviarismo" ao propor um modelo inovador de cidade. 0 projeto do Cheong-Gye é a culminação dessa opção política que, de acordo com publicações do Seoul Metropolitan Government (2005), propõe uma mudança de paradigma urbanístico. 0 esforço histórico voltado para o desenvolvimento de uma indústria automotriz levara a cidade à construção das vias expressas e esse processo havia privado a cidade de sua escala humana. Na última década do século XX, Seul vira a população da área central diminuir em 66\% (Hwang, 2007), assim como também diminuía o número de lojas e a atividade industrial. 0 centro perdia vitalidade econômica e demográfica, ainda que a capital se reafirmasse como ponto dinâmico da economia do país. Além disso, em que pese o colossal custo das estruturas permanentemente erigidas para compor o viário, Seul sofria com frequentes congestionamentos crônicos, penalizando a circulação intraurbana seja de cargas ou pessoas.

\section{O ressurgimento do rio como peça de marketing político}

É nesse contexto de declínio do centro e crise de circulação que emerge a polêmica ideia de demolição da via elevada sobre o leito do Cheong-Gye. 0 principal argumento que se levantou em prol dessa solução radical foi a ineficácia daquela estrutura como 


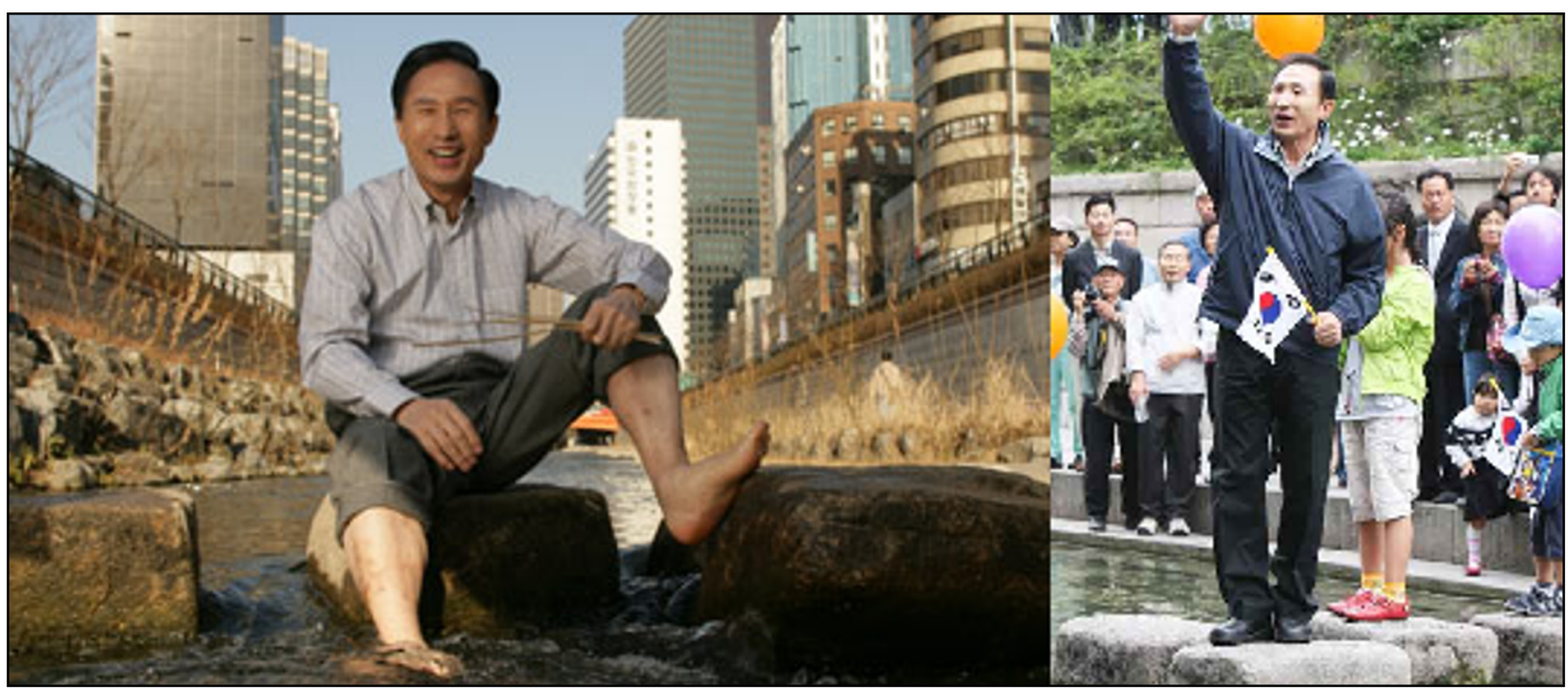

Figura 10 - 0 Cheong-Gye como Ferramenta Eleitoral

Fonte: Walsh (2007).

promotora da circulação viária. De fato, uma série de estudos vem sustentando a tese de que a oferta de uma via pretensamente desimpedida constitui um estímulo desproporcional ao uso do automóvel, introduzindo no sistema viário uma sobrecarga de demanda maior do que a elevação da capacidade de circulação representada pela sua introdução. DeCorla-Souza \& Cohen (1999), Mogridge (1995) e Pas \& Principio (2007) sustentam que esse tipo de via elevada contribuiria para a piora do trânsito local.

"Mandei demolir tudo, de uma só vez. Diziam que eu era louco!" Foi assim que o Dr. Yang Yoon-Jae, vice-prefeito de Seul entre 2002-2006, defendeu o projeto aos autores deste artigo, em novembro de 2011. Yang afirmou que confiava nos argumentos técnicos em que o projeto se ancorara, prevendo que a resistência inicial refluiria tão logo os resultados começassem a surgir. Para a operação, Dr. Yang contou com a anuência do então prefeito, Lee Myung-Bak, e com a liberdade de ação conferida por um Estado burocratizado e pouco permeável a controles sociais cotidianos. Conformando um padrão relativamente autoritário de gestão da cidade, Lee Myung-Bak aceita o risco da empreitada ancorado na convicção de que a redução da oferta de vias, associada à restrição dos estacionamentos na área central, não traria prejuízos à circulação e, além disso, as consequências paisagísticas do projeto catapultariam a popularidade do prefeito tão logo se concluísse seu ciclo de implementação. Como indicam as medições realizadas por Chung et al.
(2012), efetivamente não houve redução na velocidade média dos veículos circulando naquela região. Yang estava certo tanto com respeito ao trânsito quanto em seu prognóstico sobre o entusiasmo desencadeado pelo projeto.

No entanto, para fazer jus às necessidades simbólicas da nova "cidade mundial", a reforma proposta abarcara também a renovação de parte da tradicional área central da cidade, incluindo a retirada do tamponamento do córrego e a despoluição do curso d'água, a reforma do sistema de esgoto, de pontes, de vias de circulação e iluminação, além da promoção de profundas alterações no uso do solo adjacente. Aliás, o discurso precisava se revestir de certa monumentalidade e verniz filosófico. Seul precisava, assim, se transformar em uma cidade "orientada para o ser humano e zelosa com o meio ambiente" e, para isso, propôs-se o resgate de seus 600 anos de história, a criação de espaços culturais de preservação do patrimônio, bem como a restauração do ambiente ecológico severamente castigado pela urbanização (Križnik, 2011).

Com o êxito do projeto, Lee colheu a popularidade que o elegeu presidente da República. Em 2007, uma reportagem da Revista Time apresentava-o como exemplo de "heroísmo ambiental", declarando-o um "líder" e um "visionário". Imagens do ressurgimento de um córrego que muitos jovens sequer suspeitavam existir inundaram as mídias. Revertendo a onda de centro-esquerda iniciada em 1997, Lee ganha as eleições presidenciais. 


\section{Aspectos gerais do projeto e sua execução}

0 projeto Cheong-Gye foi levado a cabo por um consórcio formado pelo Governo Metropolitano ${ }^{6}$, por Institutos de Pesquisa e por grupos de cidadãos organizados, cada qual responsável por um domínio do projeto. Ao Governo Metropolitano coube estabelecer um plano básico de atuação, bem como conduzir a operacionalização do processo. Aos grupos de pesquisa cabia principalmente o acompanhamento de problemas relacionados ao tráfego, ao passo que os residentes participantes formaram um comitê de acompanhamento do projeto, atuando para garantir a consideração de suas necessidades pontuais, como dificuldade em acessar seus lares durante a obra. Não cabia aos moradores, contudo, definir os contornos estruturais do projeto. Ou seja, coube ao Governo Metropolitano um inquestionável protagonismo.

O ciclo completo, incluindo a demolição da via elevada, consumiria pouco mais de três anos, entre julho de 2003 e setembro de 2005. Inicialmente, e para resolver o problema estrutural e minimizar o impacto da demolição, a estratégia adotada foi dividir a extensão da via expressa em três canteiros de obra distintos e simultâneos. 0 desmantelamento da estrutura aérea foi concluído em cinco meses, a despeito da desconfiança inicial quanto aos possíveis impactos para a fluidez do trânsito na cidade. Já a retirada total da cobertura do Cheong-Gye-Cheon só seria concluída no final do ano seguinte ao início do projeto. A demolição da estrutura gerou um total de 680 mil toneladas de lixo, dos quais a totalidade das sobras metálicas e $95 \%$ do concreto e do asfalto foram reciclados, em consonância com o plano do governo de defender o projeto como solução ambientalmente correta (Seoul Metropolitan Government, 2006, p. 24).

0 córrego foi descoberto e restaurado com o intuito de devolver-lhe a vitalidade perdida, com orla e passeios ao longo das margens (Figura 11). Devido às constantes cheias, particularmente a um traumático episódio de enchente causado por chuvas torrenciais em 2001, e considerando a variação no volume da água ao longo do ano por causa das monções, foram projetadas áreas para transbordo da água e introduzidos recuos

\footnotetext{
${ }^{6}$ Governo Metropolitano de Seul é a instância administrativa eleita para governar a Região Metropolitana de Seul. Possui um prefeito e três vice-prefeitos eleitos para organizar a administração dos 25 Distritos autônomos $(g u)$ e dos 522 subdistritos (dong) que compõem a Grande Seul.
}

e aterros de absorção (Figura 12). Foram construídos terraços e calçadas em nível ao longo do curso d'água, com passeios junto ao nível mais baixo. Na margem mais alta, foram instaladas separadamente linhas coletoras de esgoto e de águas pluviais.

Por ser um córrego intermitente e com o intuito de evitar as secas dos períodos de estiagem, a água para curso restaurado é bombeada do Rio Han, purificada e distribuída em quatro pontos ao longo do Córrego. Adicionalmente e após passar pelas estações de tratamento, o esgoto tratado fornece o volume necessário de água para o Cheong-Gye-Cheon, de modo que o novo córrego seria alimentado por águas que não emanam dos mananciais que antes abasteciam o velho riacho, pois a urbanização e a impermeabilização haviam eliminado a maioria dos antigos afluentes. Ou seja, o novo córrego tornou-se, fundamentalmente, um curso artificial de água, ainda que a recuperação de conexões com outros cursos, como o córrego Jungraechon e o Rio Han, tenham possibilitado a conservação ecológica das zonas úmidas compartilhadas. A água que vem do Han é tratada em várias estações e cria um fluxo contínuo para o Cheong-Gye, dando a ele uma profundidade média de $40 \mathrm{~cm}$ durante a maior parte do ano.

De acordo com o Dr. Yang Yoon-Jae, em entrevista já mencionada, houve a defesa da despoluição das águas de mananciais inexistentes. No entanto, restava apenas uma galeria alimentada por esgotos, cuja água provinha da alimentação dos edifícios pela rede de águas tratadas, além de águas pluviais. Para reintroduzir essa água no córrego, após limpa, o sistema de esgotamento criado opera uma capacidade de tratamento três vezes maior do que o máximo de despojos gerado pela área restaurada (Seoul Metropolitan Government, 2006, p. 24). Além disso, foram instaladas uma soleira ao longo do curso descoberto do córrego, bem como uma linha extra de coletores de esgoto que desembocam nas estações de tratamento.

Ao longo do curso d'água, foram projetadas duas vias de cada lado, uma margeando o córrego e outra via de acesso às ruas transversais. Embora de tamanho reduzido, apenas $5 \mathrm{~m}$ de largura, a sua existência permite o deslocamento de automóveis e o acesso às áreas lindeiras. Ruas de pedestres foram projetadas ao longo das margens, bem como ao longo das calçadas de acesso ao comércio local. 0 acesso à orla do Córrego é feito através das pontes e em vários pontos ao longo de ambas as margens, 

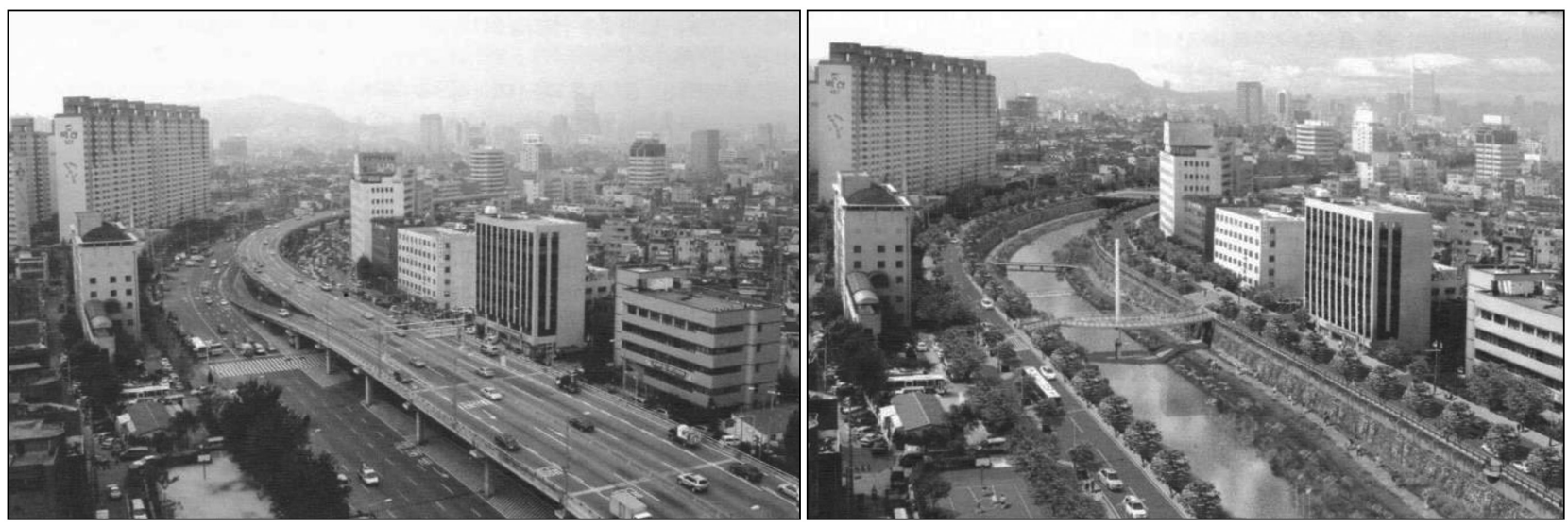

Figura 11 - 0 projeto de recriação do Cheong-Gye

Fonte: Seoul Metropolitan Government $(2004$, p. 5).
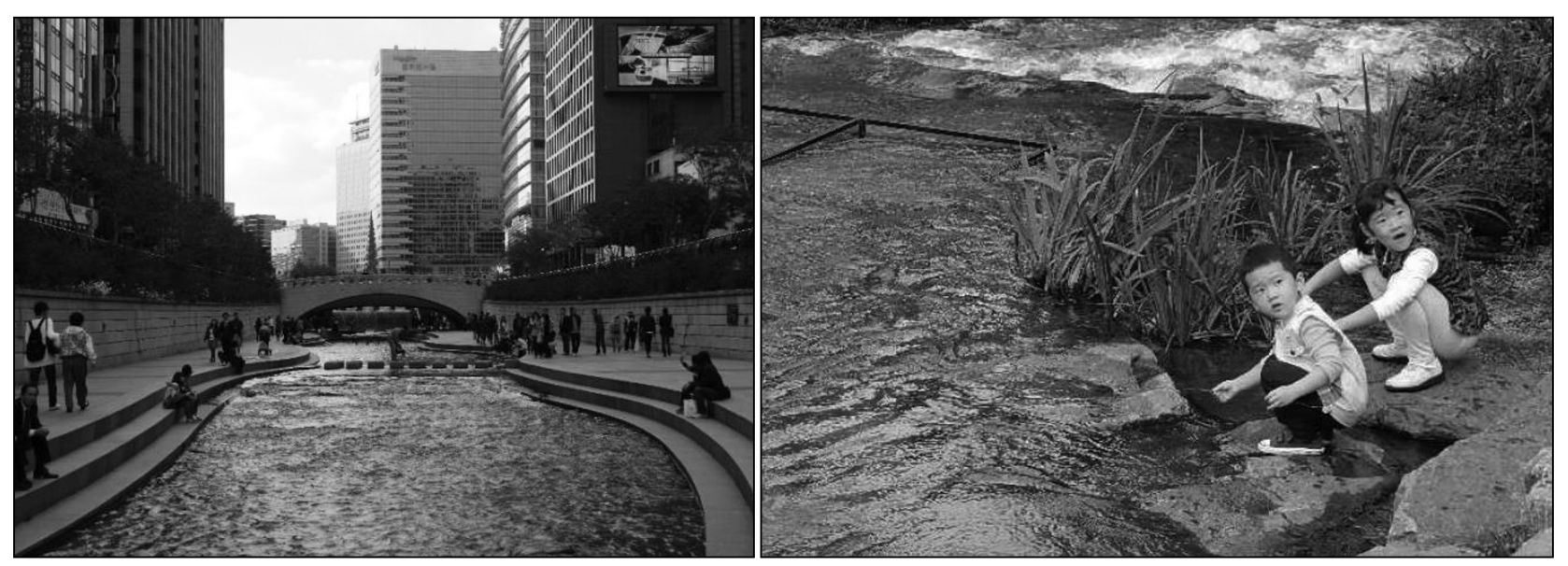

Figura 12 - Os resultados do projeto de recriação do Cheong-Gye

Fonte: Acervo dos autores.

totalizando 17 entradas. Foram mantidas as pontes previamente existentes ${ }^{7}$ e outras foram projetadas para aumentar a conexão entre as margens norte e sul, totalizando 22 pontes, todas elas com acesso a pedestres sendo duas exclusivas. 0 projeto paisagístico devolveu à cidade, a um só tempo, um espaço verde de quase $6 \mathrm{~km}$, cortando o eixo leste-oeste, e um veio d'água inexistente havia quatro décadas. Desses $6 \mathrm{~km}$, 3,6 constituem uma linha contínua de área verde para pedestres, ciclistas e animais. A área projetada se tornou um campo de recreação, passeio e descanso, com plantas, orla visitável com passagens transversais, além de atração turística cuja fama transborda os limites do país (Figura 13).

O desenvolvimento do projeto, a despeito da insegurança inicial, contribuiu para a melhora

\footnotetext{
${ }^{7}$ Inclusive a restaurada ponte Gwanggyo, que conta 6 séculos de existência.
}

significativa do trânsito na capital sul-coreana ao recomendar mudanças radicais nos usos do transporte individual e aumentar a acessibilidade ao centro através do transporte coletivo. Com as obras, o governo metropolitano investiu na oferta de transporte público e na melhoria da malha viária propondo, inclusive, drásticas restrições ao estacionamento de automóveis. As conexões do centro com os bairros adjacentes foram melhoradas com a adição das pontes, conexão com cinco linhas de metrô nas proximidades e 18 linhas de ônibus servindo para os deslocamentos dentro do centro e centro-bairros. Entre o início do projeto, em 2003, até sua finalização em 2005, houve um crescimento de $15,1 \%$ no número de passageiros de ônibus e 3,3\% no número de passageiros de metrô ${ }^{8}$.

\footnotetext{
${ }^{8}$ De acordo com The Korean Transport Institute (ITDP, 2012).
} 

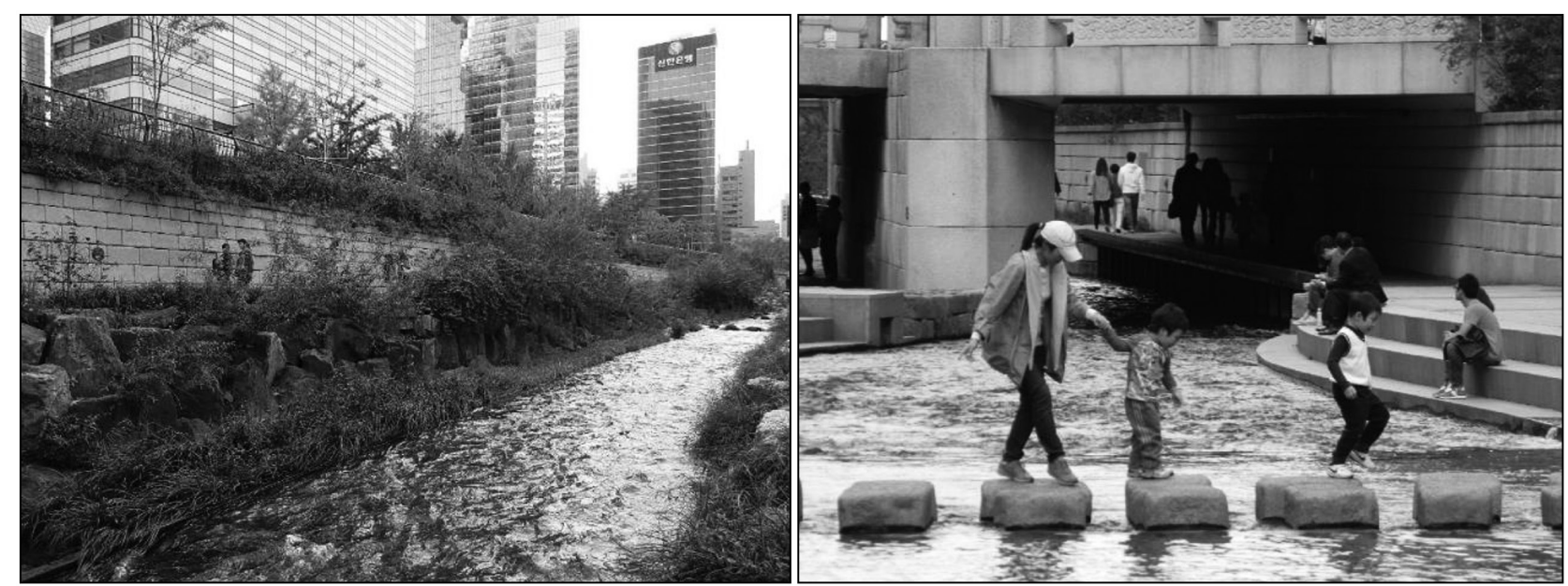

Figura 13 - Os resultados do projeto de recriação do Cheong-Gye Fonte: Acervo dos autores.

\section{Conclusão}

Ao final do século XX, Seul já era contada entre as maiores cidades do mundo, com seus 22 milhões de habitantes compreendendo quase a metade da população do país. 0 sucesso econômico alcançado pelo país possibilitou um desenvolvimento urbano, material e social então sem precedentes no mundo em desenvolvimento, alçando a capital ao reconhecimento internacional. Os eventos esportivos da década de 1980 também serviram como impulsionadores do processo de remodelação da cidade. Elevada ao patamar de "Cidade Global" ainda nos anos 90, a capital do "Milagre do Rio Han" se via numa encruzilhada entre fomentar o desenvolvimento urbano com base no paradigma fordista do passado ou propor outra abordagem para a resolução de problemas urbanos. Para tanto, urgia a recuperação do centro da cidade, que entrara em um processo de decadência havia algumas décadas.

Ao demolir a via elevada e a cobertura do leito do Córrego Cheong-Gye, visava-se a criação de oportunidades, tanto ecológicas quanto recreativas, ao longo de sua margem. Conseguiu-se criar um melhor ambiente público melhorando as condições de vida ao ar livre no centro de Seul. Temia-se um colapso no sistema de transportes, o que não veio a acontecer. Pelo contrário, a demolição da via expressa provocou uma reorientação nos usos tanto do transporte público quanto do individual, com o aumento das viagens de metrô e ônibus e a diminuição do volume do tráfego. A qualidade do ar teve uma sensível melhora, bem como se notou uma diminuição significativa da temperatura atmosférica ao longo do curso d'água. 0 projeto se provou um catalisador de investimentos para uma área comercial bastante deteriorada pela perda de vitalidade econômica, ao longo das últimas décadas. 0 ambiente do entorno sofreu grandes modificações, promovendo o revigoramento da economia da zona central.

Ainda que apresentando problemas por conta da intensificação nas mudanças nos usos do solo, a cidade tomada em seu conjunto foi relativamente exitosa quanto à criação de alternativas de moradia para os contingentes populacionais realocados (Ha, 2005). Cumpre notar que a Coreia do Sul dispõe de bons índices sociais, ao passo que seus índices de concentração de renda situam-se nos melhores patamares mundiais. 0 processo de substituição dos usos do solo no centro histórico de Seul, seguramente estimulado pelo projeto em questão, não deve ser enxergado com nosso referencial latino-americano, por partilharmos uma experiência urbana cuja marca são níveis de concentração de renda e riqueza abissalmente distintos daqueles ali vigentes.

Em um balanço geral, assim, acreditamos que o projeto Cheong-Gye constituiu um capítulo progressista na história da metrópole sul-coreana, representando ademais um álibi relevante em um processo global de questionamento da primazia do automóvel sobre outras possibilidades de uso da cidade. E ressaltamos que, em que pese todo o impacto da substituição dos usos do solo, a estrutura urbana de Seul é mais homogênea do que a da grande maioria das cidades ocidentais, aí incluídas grandes cidades europeias e 
estadunidenses. E esse tecido foi conformado pelo conjunto de iniciativas urbanísticas e regulatórias das sucessivas gestões da cidade, além da política social e econômica do governo central, inclusive sob a prefeitura de Lee Myun-Bak, durante a restauração do Cheong-Gye.

Paralelamente, cumpre examinar criticamente outra ressalva que se faz ao projeto: sua condução autoritária. Concordamos que o projeto e sua implementação trazem o sinal de uma iniciativa tecnocrática. Não havia que se esperar outra marca de um projeto executado em uma sociedade neoconfucionista, em que as hierarquias são muito naturalizadas, especialmente após longo ciclo ditatorial. Mesmo assim, essa última inflexão na longa história do Cheong-Gye, possibilitando sua restauração, não decorre de uma transição rumo a uma polícia urbana bonapartista. Em Seul, sucessivos prefeitos executaram intervenções urbanísticas com relativa liberdade ante controles sociais. Na verdade, o que a iniciativa do Cheong-Gye embute como novidade é o aumento da disputa política para ocupar a presidência do país, constituindo o cargo de prefeito da capital uma função de extrema visibilidade. A execução do projeto constituiu, assim, uma oportunidade de conquistar popularidade e qualificar o executor para a disputa do cargo mais importante do país. Desse modo, cumpre ressaltar que o ponto de ruptura na história do urbanismo "rodoviarista" em Seul não se deu no rastro da contestação socialmente organizada das mazelas criadas pelo privilégio ao automóvel. $\mathrm{Na}$ verdade, tivemos aí uma iniciativa tecnocrática encampada por um político conservador, porém racional, em busca de uma façanha a ser capitalizada como trunfo eleitoral rumo a um pleito bastante competitivo. Assim, se o peso da opinião popular não foi diretamente impresso sobre o projeto, certamente o foi indiretamente.

\section{Referências}

Amin, S. (1992). Los Angeles: United States of Plastika. Paris: Editions Anthropos.

Amsden, A. H. (1992). Asia's next giant: South Korea and late industrialization. Oxford: Oxford University Press.

Bae, H. (2011). Urban stream restoration in Korea: Design considerations and residents' willingness to pay. Urban
Forestry \& Urban Greening, 10(2), 119-126. http://dx.doi. org/10.1016/j.ufug.2011.02.001

Bedeskiee, RE. (1995). The transformation of South Korea: reform and reconstruction in the sixth Republic under Roh Tae Woo, 1987-1992. The Journal of Asian Studies, 54(2), 574-576.

Canuto, 0. (1994). Brasil e Coreia do Sul: os (des)caminhos da industrialização tardia. São Paulo: Nobel.

Chu, Y. H. (1994). The state and the development of the automobile industry in South Korea and Taiwan. In J. D. Aberbach, D. Dollar, \& K. L. Sokoloff (Eds.), The role of the state in Taiwan's development (p. 125-169). New York: M.E. Sharpe.

Chung, J. H., Hwang, K. Y., \& Bae, Y. K. (2012). The loss of road capacity and self-compliance: Lessons from the Cheonggyecheon stream restoration. Transport Policy, 21, 165-178. http://dx.doi.org/10.1016/j.tranpol.2012.01.009

Cidade Especial de Seul. (2003). A história e a cultura do córrego [cheonggyecheon-ui yeogsa-wa munhwa] (Original em Coreano). Seul: Governo da Cidade Especial de Seul.

Cumings, B. (1997). Korea's Place in the Sun: a modern history. New York: WW Norton \& Co.

DeCorla-Souza, P., \& Cohen, H. (1999). Estimating induced travel for evaluation of metropolitan highway expansion. Transportation, 26(3), 249-262. http://dx.doi. org/10.1023/A:1005161903828

Friedrichs, J. (1992). The changing downtown in a polycentric metropolitan area: a comparison of Baltimore and Hamburg. In B. Hamm, (Ed.), Progress in Social Ecology (p. 169-172). New Delhi: Mittal Publications.

Gills, B., \& Rocamora, J. (1992). Low intensity democracy. Third World Quarterly, 13(3), 501-523. http://dx.doi. org/10.1080/01436599208420292

Ha, S. K. (1984). State-developed housing in Korea: a case study from Seoul (Tese de Doutorado). University of London, Londres.

Ha, S. K. (2004). Housing poverty and the role of urban governance in Korea. Environment and Urbanization, 16(1), 139-154. http://dx.doi.org/10.1177/095624780401600112

Ha, S. K. (2005). Housing regeneration and low-income community in Seoul. In 2005 European Real Estate Society Conference (Seção J3). Dublin: ERES. 
Han, S. G., Mun, S. H., \& Huh, J. H. (2007). Changes of the micro-climate and building cooling load due to the green effect of a restored stream in Seoul, Korea. In Proceedings of Building Simulation Conference (p. 1131-1138). Bejijng: IBPSA.

Hwang, K. Y. (2007). Cheonggyecheon restoration and downtown revitalization. In Proceedings of the Hong Kong Institute of Planners (p. 82-89). Hong Kong: HKIP.

Institute for Transportation and Development Policy ITDP. (2012). The life and death of urban highways: Annual Report. New York: ITDP.

Jang, M., \& Kang, C. D. (in press). The effects of urban greenways on the geography of office sectors and employment density in Seoul, Korea. Urban Studies (Edinburgh, Scotland). http://dx.doi.org/ 10.1177/0042098015569973.

Januzzi, D. D. C. R., \& Razente, N. (2007). Intervenções urbanas em áreas deterioradas. Seminário: Ciências Sociais e Humanas, 28(2), 147-154.

Jones, L. P., \& Il, S. (1980). Government, business, and entrepreneurship in economic development: the Korean case. (Harvard East Asian Monographs, Vol. 91). Cambridge: Harvard University Press.

Jun, M. J., \& Ha, S. K. (2002). Evolution of employment centers in Seoul. Review of Urban and Regional Development Studies, 14(2), 117-132. http://dx.doi.org/10.1111/1467-940X.00051

Kang, T. H., Yoo, S. H., Kim, I. K., Cho, H. J., \& Shin, Y. U. (2012). Change of avifauna following restoration and management in Cheonggye Stream, Seoul, Korea. Journal of Korean Nature, 5(2), 107-114. http://dx.doi.org/10.7229/ jkn.2012.5.2.107

Kim, H. M., \& Han, S. S. (2012). Seoul. Cities, 29(2), 142-154.

Kim, K. J. (2012). The study of urban form in South Korea. Urban Morphology, 16(2), 149-164.

Kim, S. H., \& Jang, Y. T. (2002). Urban morphology and commercial architecture on namdaemun street in Seoul. International Journal of Urban Sciences, 6(2), 143-156. http://dx.doi.org/10.1080/12265934.2002.9693514

Kim, Y. H., \& Baik, J. J. (2007). Does the restoration of an inner-city stream in Seoul affect local climate? Theoretical and applied climatology, 92(3-4), 239-248.

Križnik, B. (2011). Selling global Seoul: competitive urban policy and symbolic reconstruction of cities. Revija za
Sociologiju, 41(3), 291-313. http://dx.doi.org/10.5613/ rzs.41.3.2

Krueger, A. 0. (1982). The developmental role of the foreign sector and aid Studies in the modernization of the Republic of Korea: 1945-1975. (Harvard East Asian Monographs, Vol. 87). Cambridge: Harvard University Press.

Lee, C. S. (1985). Japan and Korea: the political dimension. Stanford: Hoover Press.

Lee, T. (2003). From the editors: reflections on the First 18 Months. Academy of Management Journal, 46(1), 7-9. http://dx.doi.org/10.5465/AMJ.2003.17560967

Lee, Y. S., \& Shin, H. (2012). Negotiating the polycentric city-region: developmental state politics of new town development in the Seoul capital region. Urban Studies, 49(6), 1333-1355.

McNamara, D. L. (1990). The colonial origins of Korean enterprise: 1910-1945. Cambridge: Cambridge University Press.

Medeiros da Silva, R. L. (2012). Modelos, contramodelos e seu contexto: as respostas sul-coreana e argentina à crise da dívida como evidência da complexa interação entre o processo político e as forças da economia internacional (Tese de doutorado). Faculdade de Filosofia, Letras e Ciências Humanas, Universidade de São Paulo, São Paulo.

Mogridge, M. J. H. (1995). Modal equilibrium in congested urban networks. London: University College of London.

Pas, E. I., \& Principio, S. L. (2007). Braess' paradox: some new insights. Transportation Research Part B: Methodological,31(3), 265-276. http://dx.doi.org/10.1016/ S0191-2615(96)00024-0

Rii, H. U., \& Ahn, J. S. (2002). Urbanization and its impact on Seoul, Korea. In 2001 Forum on Urbanizing World and UN Human Habitat II (p. 83-100). New York: Columbia University.

Sen, S., \& Bell, M. J. (2001). Towards a typology of urban design problems and solutions for downtown revitalization: some evidence from the mayor's institute on city design. In M. A. Burayidi (Ed.), Downtowns: revitalizing the centers of small communities (p. 121-145). New York: Routledge.

Seoul Metropolitan Government. (2004). Revived Cheong Gye-Cheon: urban design studio exhibition, UnivHarvard. Seul: Governo Metropolitano de Seul. 
Seoul Metropolitan Government. (2005). Back to a future: CheongGyeCheon Restoration Project. Seul: Governo da Cidade Especial de Seul.

Seoul Metropolitan Government. (2006). CheongGyeCheon Restoration Project. Seul: Governo da Cidade Especial de Seul.

Shin, H. B. (2009). Property-based redevelopment and gentrification: the case of Seoul, South Korea. Geoforum, 40(5), 906-917. http://dx.doi.org/10.1016/j.geoforum.2009.06.009

Shin, H. B., \& Kim, S. H. (in press). The developmental state, speculative urbanisation and the politics of displacement in gentrifying Seoul. Urban Studies (Edinburgh, Scotland) http://dx.doi.org/10.1177/0042098014565745.
Shin, I. K., Yi, H. B., \& Bae, Y. J. (2011). Colonization and community changes in benthic macroinvertebrates in Cheonggye Stream, a restored downtown stream in Seoul, Korea. Journal of Ecology and Environment, 34(2), 175-191.

Walsh, B. (2007, outubro 17). Lee Myung Bak. Time Magazine. Recuperado em 23 de setembro de 2015, de http://content.time.com/time/specials/2007/ article/0,28804,1663317_1663319_1669884,00.html

Woo, J. E. (1991). Race to the swift: state and finance in Korean industrialization. New York: Columbia University Press.

Recebido: Ago. 04, 2014

Aprovado: Abr. 17, 2015. 